3. Organisation for Economic Co-operation and Development, Recommendation of the Council on Artificial Intelligenc. Режим доступу: https://legalinstruments.oecd.org/en/instruments/OECD-LEGAL-0449

4. Урядовий портал. Сдиний веб-портал органів виконавчої влади. Електронний документ. Режим доступу: https://www.kmu.gov.ua/npas/ pro-shvalennya-koncepciyi-rozvitku-shtuchnogo-intelektu-v-ukrayinis21220

5. Баранов О.А. Ідентифікація робота 3 штучним інтелектом як суб'єкта права. Інтернет речей: проблеми правового регулювання та впровадження. Матеріали другої наук.-практ. конф. Упор. В.М. Фурашев, С.О. Дорогих. К. 2018. 168 с.

6. Вікіпедія. Штучний інтелект. Електронний документ. Режим доступу: https://uk.wikipedia.org/wiki/\%D0\%A8\%D1\%82\%D1\%83\%D1\% 87\%D0\%BD\%D0\%B8\%D0\%B9_\%D1\%96\%D0\%BD\%D1\%82\%D0\%B5\% D0\%BB\%D0\%B5\%D0\%BA\%D1\%82

DOI https://doi.org/10.30525/978-9934-26-148-0-18

\title{
СУЩНОСТЬ ИННОВАЦИОННОЙ ДОКТРИНЫ АНТИДЕЛИКТНЫХ ОРГАНОВ И АНТИДЕЛИКТОЛОГОВ
}

\author{
Кириченко А. А.
}

доктор юридических наук, профессор, заведующий кафедрой права факультета экономики и права

Международного классического университета имени Филиппа Орлика

Садовская К. С.

соискатель высшего образования по спечиальности 081 Право квалификационного уровня младший бакалавр факультета экономики и права Международного классического университета имени Филиппа Орлика 2. Николаев, Украина

Инновационные наименования и перечень антиделиктных органов и антиделиктологов следует представить так : 1. Суд, судья. 2. Прокуратура, прокурор. 3. Публичнотура, преследователь. 4. Адвокатура, адвокат. 5. Следотура, следователь. 6. Экспертнотура, эксперт. 7. Госбезопаснотура, сотрудник госбезопасности. 8. Ордистатура, 
ордист. 9. Налоготура, налоговик. 10. Таможеннотура, таможенник. 11. Пограничнотура, пограничник. 12. Эмчасэснотура (МЧС), эмчаэсник. 13. Пожарнотура, пожарник. 14. Исполнитотура, исполнитель. 15. Ревизийнотура, ревизор. 16. Трудозащитнотура, трудозащитник. 17. Потберзащитнотура (охрана прав потребителей), потребзащитник. 18. Ценозащитнотура, ценозащитник. 19. Недрозащитнотура, недрозащитник и др.

\section{Инновационная же доктрина антиделиктных органов} реализуется посредством коренного реформирования всех существующих и появления некоторых новых антиделиктных органов, что обосновывается таким образом.

Фактически в силу требований ч. 2 ст. 3 , ч. 6 ст. 55 и ч. 2 ст. 102 Конституции Украины [3] украинское государство является собственно президентской республикой. Ведь только Президент украинского государства и никакой иной субъект властных полномочий в конечном итоге отвечает за неукоснительное соблюдение Основного закона и иных правовых актов и правового статуса всех соотечественников [2, с. 13]. Для этого ч. 6 ст. 55 Конституции Украины и предоставляет президенту государства в распоряжение любые средства, прямо не запрещенные законом [3], а требования ч. 2 ст. 3 и ч. 2 ст. 102 Конституции Украины [3] возлагают на данного особого субъекта властных полномочий прямо таки обязанность с тем, чтобы он немедленно пресекал незаконные деяния и/либо отменял нелегитимные решения и/или правовые акты иных субъектов властных полномочий, а также хотя бы и окончательные, но незаконные судебные решения ${ }^{1}$ [2, с. 13]. При этом следует иметь в виду, что отсутствуют сроки давности для применения президентом государства на выполнение названных требований ч. 2 ст. 3 , ч. 6 ст. 55 и ч. 2 ст. 102 Конституции Украины [3] собственно указанные средства обеспечения неукоснительного соблюдения на территории государства любых правовых актов и правового статуса всех соотечественников, практически - всех без исключения лиц, проживающих или с иным правовым статусом находящихся на территории государства. Сроки давности существуют с определенными исключениями лишь для применения мер карательновоспитательной юридической ответственности [2, с. 13-14].

${ }^{1}$ Собственно данные обстоятельства и исключают президента государства из перечня государственных органов, которые обязаны на основании требований ч. 2 ст. 19 Конституции Украины действовать лишь на основании, в пределах полномочий и способом, которые предусмотрены Конституцией и законами Украины [2, с. 13; 3]. 68 
Указанные цели также никак нельзя достичь без реального коренного преобразования и полномочий органов прокуратуры в Правую руку президента государства с возвращением и обновлением собственно в Конституционном кодексе Украины (а равно восстановить или предусмотреть в Основном законе любой иной страны мира) естественной функции прокуратуры по осуществлению надзора за точным, однообразным и неуклонным соблюдением законов и иных правовых актов со стороны любых социосубьектов, а как следствие, и за наиболее эффективным, рациональным и качественным выполнением субъектами властных полномочий базисной конституционной обязанности государства по познанию, признанию, обеспечению и неукоснительному соблюдению правового статуса всех соотечественников, предупреждению нарушения данного правового статуса и в случае нарушения - по максимально полному его восстановлению [2, с. 14].

Поэтому институт президента государства и органы прокуратуры должны приобрести статус особой надзорной гиперветви государственной власти за осуществлением указанного надзора за точным, однообразным и неуклонным соблюдением законов и иных правовых актов со стороны представителей иных ветвей государственной власти (правотворческой, правоприменительной, антиделиктной) и остальных субъектов властных полномочий и всех иных социосубьектов государства, а как следстьие, и за наиболее эффективным, рациональным и качественным выполнением субъектами властных полномочий базисной конституционной обязанности государства по познанию, признанию, обеспечению и неукоснительному соблюдению правового статуса всех соотечественников, оперативному предупреждению нарушения их правового статуса и по максимально возможному его восстановлению [2, с. 14].

Этот инновационный статус института президента государства и органов прокуратуры согласуется с требованиями п. 57 разд. IV Доклада Венецианской комиссии «Верховенство права» согласно которым, «сверх того, должно существовать учреждение или организация - как некий обвинитель, которое в определенной мере должно быть тоже независимой от исполнительной власти и которое обеспечивает, чтобы нарушитель закона - даже если потерпевшие не заявляют об этом - предстал перед судом» [1; 2, с. 14-15].

В таком аспекте существующую функцию прокуратуры по процессуальному руководству следствием следует передать руководителям следственных подразделений следотуры (объединенной на основе принципа единоначалия по всему спектру 
подследственности). Функцию же обвинения и иной защиты правового статуса потерпевшего следует передать заново созданному антиделиктному органу - публичнотуре, который тоже должен действовать на принципе единоначалия, получать зарплату сотрудников и иное материально-техническое обеспечение только от государства и иметь два подразделения : а) обвинения и иной защиты правового статуса потерпевшего во всех видах судопроизводства; б) иной юридической помощи.

Коренному реформированию следует подвергнуть и адвокатуру, которая также должна действовать на принципе единоначалия, получать зарплату сотрудников и иное обеспечение только от государства, а получение какой-либо материальной и иной выгоды от клиента или в его интересах от иного лица следует расценивать, как и в отношении любых иных антиделиктологов, не иначе как взятка (получение неправомерной выгоды) или поборы со значительно усиленной (вплоть до смертной казни) антикриминальной ответственностью, а в структуре данного антиделиктного органа также должны быть два подразделения : a) защиты правового статуса правонарушителей во всех видах судопроизводства; б) иной юридической помощи.

В контексте наиболее эффективного, рационального и качественного познания, признания, обеспечения и соблюдения правового статуса граждан и иных социосубъектов, оперативного предупреждения его нарушения, в случае нарушения максимально полного восстановления и неуклонного привлечения виновных в совершении этих правонарушений к соответствующему виду, характеру и степени тяжести юридической ответственности должна быть коренным образом реформирована сущность и функции и всех иных антиделиктных органов, особенно, следотуры, экспертнотуры, ордистатуры и исполнитотуры, которые также должны быть в виде единого антиделиктного органа и построены на принципе единоначалия с сочетанием по принципу специализации всех существующих видов :

1. Следствия - в пределах специализации такой деятельности по антиделиктным органам, которые ее осуществляют.

2. Экспертных исследований во всех основных видах судопроизводства : конституционном, антикриминальном, административном, трудовом, де-факто имущественно-договорном и деюре имущественно-договорном.

3. Ордистической деятельности - в пределах специализации такой деятельности по антиделиктным органам, которые ее осуществляют. 
4. Исполнительной деятельности - исполнение окончательных судебных решений или решений иных полномочных органов по всем видам судопроизводства с наличием только двух департаментов :

4.1. Исправительно-трудового или пенитенциарного (исполнение судебных решений по осуждению подсудимого к смертной казни или иной высшей мере наказания и лишения или иного ограничения его свободы).

4.2. Исполнение иных судебных решений и исполнительных производств.

\section{Литература:}

1. Верховенство права. Доповідь, схвалена Європейською Комісією «За демократію через право» (Венеціанською Комісією) на 86-му пленарному засіданні. Венеція. 25-26 бер. 2011 p. URL: https://www.venice.coe.int/webformsdocuments/default.aspx?pdffile= CDL-AD(2011)003rev-ukr

2. Кириченко А.А. Инновационные наименования и перечень антиделиктных органов и деятельности и антиделиктологов. Імперативи розвитку права та держави : матеріали IV-тої (XV) Всеукр. студ. наук.практ. конфер., 25 бер. 2021 р. Миколаїв : НУК ім. адм. Макарова, 2021. C. 11-16.

3. Конституція України : закон України від 28 черв. 1996 р., № 254к/96-ВР. Відомості Верховної Ради України (ВВР), 1996, № 30, ст. 141, із змінами, згідно із законом України № 27-ІХ від 3 вер. 2019 р., BBP, 2019, № 38, ст. 160. URL : http://zakon2.rada.gov.ua/laws/show/ 254к/96-вр 